\title{
Understanding consumer intention to pay by contactless credit cards in Taiwan
}

\author{
Yu-Min Wang* and Wei-Cheng Lin \\ Department of Information Management, \\ National Chi Nan University, \\ 1 University Rd. Puli, Nantou Hsien, 54561, Taiwan \\ Email: ymwang@ncnu.edu.tw \\ Email: s94213506@ncnu.edu.tw \\ ${ }^{*}$ Corresponding author
}

\begin{abstract}
Contactless payment is a revolutionary innovation in transaction payments. Little is known, however, about what shapes consumers' willingness to use this method. This study investigates the antecedents of consumer intention to pay using contactless credit cards, along with relationships among these antecedents. Based on the technology acceptance model and innovation diffusion theory, eight variables (usefulness, ease of use, perceived behavioural control, compatibility, perceived risk, trust, personal innovativeness, and consumer involvement) are proposed to analyse consumer decisions to pay using contactless credit cards. The model was evaluated using survey data from 246 consumers in Taiwan. The results indicate that compatibility and perceived risk are key determinants of consumers' use intention to pay by contactless credit cards. However, consumers do not appear to consider the main constructs of TAM in their use intention. This study extends the knowledge of consumers' payment-decision making and provides insights into how to promote contactless credit cards.
\end{abstract}

Keywords: contactless payment; contactless credit card; consumer use intention; transaction payment.

Reference to this paper should be made as follows: Wang, Y-M. and Lin, W-C. (2019) 'Understanding consumer intention to pay by contactless credit cards in Taiwan', Int. J. Mobile Communications, Vol. 17, No. 1, pp.1-23.

Biographical notes: Yu-Min Wang is a Professor in Information Management at National Chi Nan University in Taiwan. He received his $\mathrm{PhD}$ in Information Management at National Sun Yat-Sen University in Taiwan. His research interests include enterprise information system, information system adoption, electronic commerce, e-learning, internet entrepreneurship, and knowledge management. His work has been published in academic journals such as Information and Management, Computers in Human Behaviour, International Journal of Operation and Production Management, International Journal of Service Industry Management, Electronic Commerce Research and Applications, Computers and Education, and Psychological Reports.

Wei-Cheng Lin is a Master of Information Management at National Chi Nan University. His specialisation and research interests are focused on information management and mobile technologies. 
This paper is a revised and expanded version of a paper entitled 'Consumer intention to pay by contactless credit card: antecedents and their interaction effects' presented at the 9th Annual Hawaii International Conference on Business, Honolulu, Hawaii, 12-15 June, 2009.

\section{Introduction}

Advances in mobile and wireless communication technologies such as near field communication (NFC), radio frequency identification (RFID), infrared (IR), Bluetooth, and carrier-based mobile technologies, have significantly innovated transaction and payment methods. They allow consumers' transaction payments in a contactless and mobile way. One of the innovative mobile payment instruments that have high potentials is the contactless credit card (Lomax, 2005; Smart Payment Association, 2016). It is also called 'mobile' or 'proximity' credit cards or 'tap-and-go' cards (Henry et al., 2015; Kemp, 2013; Ondrus and Pigneur, 2009). Using contactless credit cards, consumers can hold their cards near a reader at checkout instead of swiping them or handing them to a cashier (Card Technology Today, 2006). Consumers benefit from transaction efficiency, security, and convenience (Dobschuetz, 2015; Lomax, 2005; Singh et al., 2004; Smart Payment Association, 2016; YouGov, 2012). Merchants experience lower costs and increased service efficiency (Liebana-Cabanillas et al., 2014a).

There are two types of contactless credit cards (Dobschuetz, 2015; Tompkins, 2015). The first type is the extension of traditional electronic magnetic cards. A RFID chip and antenna are embedded in the card. The chip contains identification and credit information. The antenna's functions are to send and receive data, and power up the chip via radio frequency. Visa payWave, American Express Expresspay, and MasterCard PayPass are examples of this type of contactless credit cards (Wikipedia, 2016). The other type is NFC-enabled mobile phones. NFC is a new wireless short-range communication technology. A smart mobile phone built-in NFC chipsets can emulate a credit card for payment (Ondrus and Pigneur, 2009).

Given the apparent benefits for both consumers and merchants, many reports have predicted that contactless credit cards will become the preferred payment instrument for a growing number of consumers (Hewgill, 2008; Leong et al., 2013; Liebana-Cabanillas et al., 2014a; Smart Payment Association, 2016).

Although the user number and transaction volume of contactless credit cards continue to grow, the proportion of the total transaction value of contactless payments is still low in the overall expenditures (Collinson, 2015; Dobschuetz, 2015; Osborne, 2015; RFi media centre, 2016). In the UK, contactless payments only accounted for $4 \%$ of the overall card expenditures in 2015 (Dobschuetz, 2015). Only 9\% of US citizens reported experiences of using a contactless payment in 2015 (Smart Payment Association, 2016). In Canada, contactless credit card payments accounted for about $19.3 \%$ of the volume of credit card payments in 2013 (Henry et al., 2015). These statistical figures may imply that consumers do not prefer to use contactless credit cards for payment. Therefore, there is a need to analyse the intention of adopting and using this new payment instrument (Fung et al., 2015; Henry et al., 2015; Leong et al., 2013; Liebana-Cabanillas et al., 2014b; YouGov, 2012; Zhou, 2013). 
Most prior studies focused on the initial decision to adopt contactless or mobile payments, such as studies by as Kim et al. (2010), Leong et al. (2013) and Wang (2008). These studies focused on whether people are willing to accept or apply for this new payment instrument. However, post-adoption usage has seldom been examined and analysed (Zhou, 2013). Little is known about factors relating to consumers' willingness to use contactless credit cards for payment. With the progress of information and communication technologies, consumers have more and more payment instrument options. Consumer decisions to choose payment options have become complex and diverse. The purpose of this study is to develop and empirically test a model that examines the antecedents of consumer intention to pay using contactless credit cards and to explore relationships among these antecedents. The analysis of this study focuses on understanding consumers' concerns regarding the use of contactless credit cards when they make transactions. The results will lead to further understanding of what motivates and inhibits consumer intention vis-à-vis the use contactless credit cards for payment. This study will be of value to practitioners to improve and increase consumers' use of contactless credit cards.

The remainder of the paper is organised as follows. Section 2 introduces the theoretical background and describes the hypotheses. Section 3 presents the research methodology and Section 4 highlights the empirical results. Finally, the results are discussed and conclusions are drawn.

\section{Theoretical background}

\subsection{Technology acceptance model}

There is a growing body of academic research that focuses on examining the factors affecting information technology acceptance and use intention among users. Among the different models of technology adoption that have been proposed, Davis' (1989) technology acceptance model (TAM) remains widely applied by information systems researchers (Leong et al., 2013; Lin et al., 2017; Wang et al., 2006).

As depicted in Figure 1, TAM consists of perceived usefulness, perceived ease of use (PEOU), attitude towards use, behavioural intention to use, and actual system use. TAM asserts the belief-attitude-intention-behaviour relationship, where user adoption behaviour is determined by the intention to use a particular system, which in turn is determined by user attitudes. Two beliefs - perceived usefulness and PEOU - are instrumental in this model in terms of determining user attitudes. This model has been validated as a powerful and parsimonious framework for explaining IT user adoption.

Although there are some extensions of TAM such as TAM2 (Venkatesh and Davis, 2000) and UTAUT (Venkatesh et al., 2003), this study still choose TAM as the base model for three reasons. First, TAM is more parsimonious and easier to extend (Olschewski et al., 2013). Second, paying with contactless credit cards is a voluntary behaviour. Social factors have no significant effect on this setting (Castaneda et al., 2009). Third, TAM is the most widely used model in the literature on mobile service contexts (Liebana-Cabanillas et al., 2014a, 2014b).

Not all findings regarding the effects of attitudes in TAM have proved significant (Fu et al., 2006; Lederer et al., 2000). Therefore, many studies removed the attitude factor to simplify the model, and instead directly investigated the effects of ease of use and 
usefulness on intention ( $\mathrm{Wu}$ and Wang, 2005; Yi et al., 2006). To maintain a parsimonious research model, the attitude factor was also excluded from this study.

Although TAM provides a good starting point for building the research model, the fundamental constructs in TAM do not fully reflect the technological and contextual factors that influence users' adoption of a specific technology (Moon and Kim, 2001). Researchers in technology adoption need to account for these additional factors if they can effectively predict users' intention to adopt (Davis, 1989; Wang et al., 2006).

Figure 1 Technology acceptance model

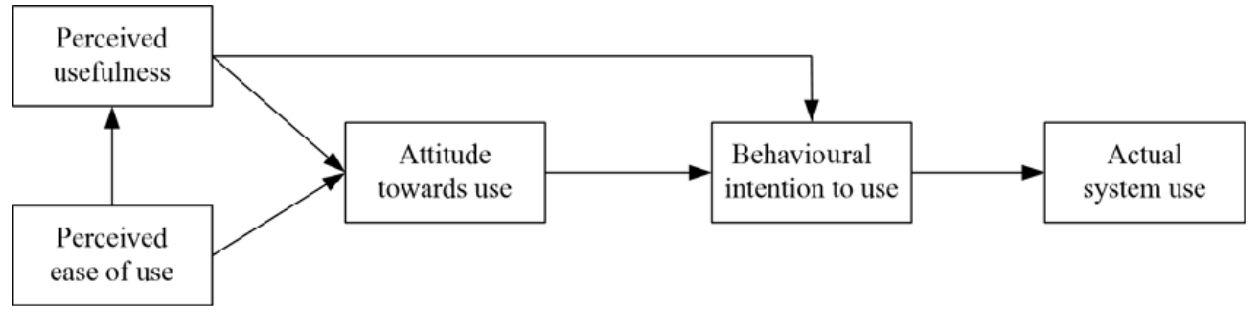

\subsection{Factors affecting the consumer intention to use contactless credit cards for payment}

Because contactless credit cards are in the early stage of diffusion, little is known about the factors that affect consumer intention to use them for payment. Since contactless credit cards are a type of media which facilitates transaction payments, we examine literature that relates to consumers' adoption of innovative transaction mediums as well as data on actual usage (Chen, 2008; Chiou and Shen, 2012; Collinson, 2015; Fung et al., 2015; Kim et al., 2010; Leong et al., 2013; Liebana-Cabanillas et al., 2014a, 2014b; Osborne, 2016; Yang et al., 2012). This literature provides a substantive foundation to identify the determinants of consumer intention to use contactless credit cards for payment.

Table 1 summarises the main studies relating to consumers' adoption of innovative transaction mediums. Three particular insights were drawn. First, the TAM's fundamental constructs - perceived usefulness and PEOU - appear to be the most widely utilised as determinants of user adoption. Second, because TAM only has two core constructs, i.e., perceived usefulness and PEOU, the explanatory power may be not good in some situations. Therefore, TAM should be supplemented and extended with other constructs to be more comprehensive (Venkatesh and Davis, 2000). Third, integrating with innovation diffusion theory (IDT) (Rogers, 1983), and adding factors related to consumer characteristics and technology perceptions (Cha, 2011; Kamarulzman, 2007; Legris et al., 2003; Rigopoulou and Chaniotakis, 2017) are good strategies for the extension of the original TAM.

Therefore, this study is based on TAM and adds the IDT construct (i.e., compatibility), consumer-related characteristics (i.e., personal innovativeness, consumer involvement, perceived behavioural control), and technology-perception variables (i.e., trust, perceived risk) to investigate what determines consumer intention to pay using contactless credit cards. 
Table 1 Studies of consumers' adoption of innovative transaction mediums

\begin{tabular}{|c|c|c|c|}
\hline Researchers & Context & Perceived variables affec & cting adoption \\
\hline Bhatti (2007) & Mobile commerce & $\begin{array}{ll}\text { - } & \text { Ease of use } \\
\text { - } & \text { Innovativeness } \\
\text { - } & \text { Perceived behaviour }\end{array}$ & $\begin{array}{l}\text { - Usefulness } \\
\text { - Subjective norm } \\
\text { al control }\end{array}$ \\
\hline Chen (2008) & Mobile payment & $\begin{array}{l}\text { - } \quad \text { Ease of use } \\
\text { - Usefulness }\end{array}$ & $\begin{array}{l}\text { - } \text { Perceived risk } \\
\text { - } \text { Compatibility }\end{array}$ \\
\hline $\begin{array}{l}\text { Chiou and Shen } \\
\text { (2012) }\end{array}$ & Internet banking & $\begin{array}{ll}\text { - } & \text { Usefulness } \\
\text { - } & \text { Trust } \\
\text { - } & \text { Perceived risk } \\
\text { - } & \text { Satisfaction }\end{array}$ & $\begin{array}{ll}\text { - } & \text { Ease of use } \\
\text { - } & \text { Attitude } \\
\text { - } & \text { Specific asset } \\
\text { investment }\end{array}$ \\
\hline $\begin{array}{l}\text { Kamarulzman } \\
\text { (2007) }\end{array}$ & Travel e-shopping & $\begin{array}{ll}\text { - } & \text { Trust } \\
\text { - } & \text { Innovativeness } \\
\text { - } & \text { Involvement } \\
\text { - } & \text { Perceived risk }\end{array}$ & $\begin{array}{l}\text { - } \text { Ease of use } \\
\text { - Usefulness } \\
\text { - } \quad \text { Opinion leadership }\end{array}$ \\
\hline Kim et al. (2010) & Mobile payment & $\begin{array}{l}\text { - Usefulness } \\
\text { - } \quad \text { Ease of use }\end{array}$ & $\begin{array}{ll}\text { - } & \text { MPS characteristics } \\
\text { - } & \text { Individual } \\
\text { differences }\end{array}$ \\
\hline $\begin{array}{l}\text { Kolodinsky et al. } \\
\text { (2004) }\end{array}$ & Electronic banking & $\begin{array}{ll}\text { - } & \text { Trialability } \\
\text { - } & \text { Complexity } \\
\text { - } & \text { Observability } \\
\text { - } & \text { Perceived risk }\end{array}$ & $\begin{array}{ll}\text { - } & \text { Relative advantage } \\
\text { - } & \text { Compatibility } \\
\text { - } & \text { Safety } \\
\text { - } & \text { Involvement }\end{array}$ \\
\hline $\begin{array}{l}\text { Liebana-Cabanillas } \\
\text { et al. }(2014 a)\end{array}$ & Mobile payment & $\begin{array}{ll}\text { - } & \text { Usefulness } \\
\text { - } & \text { Attitude }\end{array}$ & $\begin{array}{ll}\text { - } & \text { External influences } \\
\text { - } & \text { Risk }\end{array}$ \\
\hline $\begin{array}{l}\text { Lian and Lin } \\
(2008)\end{array}$ & Online shopping & $\begin{array}{l}\text { - Involvement } \\
\text { - Innovativeness }\end{array}$ & $\begin{array}{l}\text { - Perceived security } \\
\text { - Privacy concerns }\end{array}$ \\
\hline Pavlou (2003) & $\begin{array}{l}\text { Electronic } \\
\text { commerce }\end{array}$ & $\begin{array}{ll}\text { - } & \text { Trust } \\
\text { - } & \text { Perceived risk }\end{array}$ & $\begin{array}{l}\text { - } \quad \text { Ease of use } \\
\text { - } \quad \text { Usefulness }\end{array}$ \\
\hline Rugimbana (1995) & $\begin{array}{l}\text { Automated teller } \\
\text { machine }\end{array}$ & $\begin{array}{l}\text { - Convenience } \\
\text { - Ease of use } \\
\text { - Accuracy }\end{array}$ & $\begin{array}{l}\text { - } \text { Reliability } \\
\text { - Compatibility }\end{array}$ \\
\hline Sathye (1999) & Internet banking & 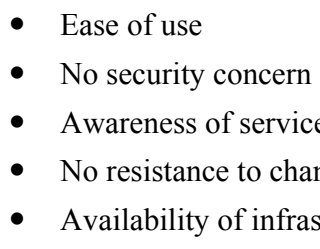 & $\begin{array}{l}\text { - Reasonable price } \\
\text { e and its benefits } \\
\text { nge } \\
\text { structure }\end{array}$ \\
\hline Wang et al. (2003) & Internet banking & $\begin{array}{l}\text { - } \quad \text { Ease of use } \\
\text { - Usefulness }\end{array}$ & - Perceived credibility \\
\hline
\end{tabular}


Table 1 Studies of consumers' adoption of innovative transaction mediums (continued)

\begin{tabular}{|c|c|c|c|}
\hline Researchers & Context & \multicolumn{2}{|c|}{ Perceived variables affecting adoption } \\
\hline $\begin{array}{l}\text { Wang and } \mathrm{Wu} \\
(2014)\end{array}$ & $\begin{array}{l}\text { Mobile self-service } \\
\text { technology }\end{array}$ & $\begin{array}{ll}\text { - } & \text { Ease of use } \\
\text { - } & \text { Usefulness } \\
\text { - } & \text { Perceived value }\end{array}$ & $\begin{array}{ll}\text { - } & \text { Perceived control } \\
\text { - } & \text { Perceived enjoyment } \\
\text { - } & \text { Perceived novelty }\end{array}$ \\
\hline $\begin{array}{l}\text { Wu and Wang } \\
(2005)\end{array}$ & Mobile commerce & $\begin{array}{l}\text { - Usefulness } \\
\text { - Compatibility } \\
\text { - Cost }\end{array}$ & $\begin{array}{l}\text { - } \quad \text { Ease of use } \\
\text { - } \quad \text { Perceived risk }\end{array}$ \\
\hline Yang et al. (2012) & $\begin{array}{l}\text { Mobile payment } \\
\text { services }\end{array}$ & $\begin{array}{ll}\text { - } & \text { Perceived risk } \\
\text { - } & \text { Perceived fee } \\
\text { - } & \text { Personal innovat } \\
\text { - } & \text { Subjective norm }\end{array}$ & $\begin{array}{l}\text { - Relative advantage } \\
\text { - Compatibility } \\
\text { ness in IT } \\
\text { d Image }\end{array}$ \\
\hline
\end{tabular}

Rogers' innovation diffusion theory (1983) is frequently applied to predict technology adoption. Rogers identifies five technological characteristics as antecedents to any adoption decision: relative advantage, compatibility, complexity, trialability, and observability. Previous studies, including Tornatzky and Klein's (1982) meta-analysis of 75 diffusion studies, find that only relative advantage, compatibility, and complexity consistently relate to innovation adoption. These findings are supported by others studies, such as Kolodinsky et al. (2004), who find that trialability and observability are not significant in predicting use of automatic bill payment and PC banking. This leads researchers to exclude these characteristics in their studies of users' adoption of innovation (e.g., Chen, 2008; Wu and Wang, 2005). Researchers generally consider the advantage construct to be analogous to the perceived usefulness construct in TAM, while complexity is understood to be extremely similar to PEOU (Leong et al., 2013; Moore and Benbasat, 1991). Drawing these perspectives together, we choose to focus on perceived usefulness (relative advantage), PEOU (complexity), and compatibility constructs as the main antecedents in the research model.

Perceived usefulness is the degree to which a person believes that a particular innovation would enhance his or her performance (i.e., by reducing the time needed to accomplish a task or providing timely information). PEOU is the degree to which a person believes that using a particular innovation would be free of effort (Davis, 1989). Compatibility is the degree to which the technology fits the potential adopter's previous experience, work practice, and needs (Fu et al., 2006). High perceived usefulness, PEOU, and compatibility have been identified as facilitators for adopting innovative services (Leong et al., 2013; Lin et al., 2017; Rogers, 1983; Shih, 2011; Wu and Wang, 2005). Accordingly, the following hypotheses are proposed:

H1. Perceived usefulness has a positive effect on consumers' intention to use contactless credit cards for payment.

H2. Perceived ease of use has a positive effect on consumers' intention to use contactless credit cards for payment.

H3. Perceived compatibility has a positive effect on consumers' intention to use contactless credit cards for payment. 
Previous studies find that PEOU has a significant effect on perceived usefulness (Kim et al., 2010; Rigopoulou and Chaniotakis, 2017; Wang et al., 2003). A consumer is likely to consider contactless credit cards to be useful when they think that they are easy to use. That is, the easier it is for a consumer to use contactless credit cards for payment, the more likely the consumer will perceive the contactless credit cards useful. The following hypothesis is thus proposed:

H4. Perceived ease of use has a positive effect on the perceived usefulness of using contactless credit cards for payment.

Compatibility may affect consumers' perceptions of a technology's usefulness (Rigopoulou and Chaniotakis, 2017; Schierz et al., 2010; Wu and Wang, 2005). Consumers have their own particular habits in which they engage in during transactions. It is unlikely, therefore, that a consumer will find an innovative payment method (e.g., contactless credit cards) as useful if it is incompatible with their payment habits. Consumers usually consider an innovation useful when its inclusion is consistent or compatible with their consumption practices. Accordingly, the following hypothesis is proposed:

H5. Perceived compatibility has a positive effect on the perceived usefulness of using contactless credit cards for payment.

Perceived behavioural control, integral to the Theory of Planned Behaviour (Ajzen, 1991), has been used to explain individual adoption and consumer behaviours. Perceived behavioural control refers to users' perceptions of the capabilities, skills, and sense of control needed to successfully perform a particular behaviour (Lu et al., 2009). The construct has a positive impact on PEOU and behavioural intention (Bhatti, 2007; Yi et al., 2006).

Even though contactless credit cards are comparatively easy to use, they still require customers to have basic skills and knowledge. Compared with traditional payment instruments, such as cash and contacted credit cards, consumers are unfamiliar with contactless credit cards for payment due to their recent introduction. This suggests that perceived behavioural control has an important influence on adoption of contactless credit cards. Thus, the following hypotheses are proposed:

H6. Perceived behavioural control has a positive effect on perceived ease of use of using contactless credit cards for payment.

H7. Perceived behavioural control has a positive effect on consumer intention to use contactless credit cards for payment.

Trust and risk perceptions are important determinants of adoption in uncertain transaction contexts (Pavlou, 2003). The innovative nature of contactless payment methods creates uncertainty in consumers' minds towards these kinds of transactions. This means trust and risk are important factors to consider in consumer adoption of contactless credit cards. Table 1 shows that the constructs of reliability, accuracy, safety, perceived security, privacy concerns, and perceived credibility frequently predict users' adoption of innovative transaction technologies. These constructs are integral to trust and risk. Trust is understood as the perceived credibility and benevolence of a target of trust (Doney and Cannon, 1997; Lin and Shih, 2008). Perceived credibility includes honesty, reliability, and integrity (Pavlou, 2003). Perceived risk is the consumer's subjective expectation of 
suffering a loss in pursuit of the desired outcome (Featherman and Pavlou, 2003). Privacy and loss from transaction inaccuracy are also the elements of perceived risk (Tsai et al., 2010). Therefore, we choose the only trust and perceived risk as constructs in the research model. The following hypotheses are proposed:

H8. Consumer trust has a positive effect on consumer intention to use contactless credit cards for payment.

H9. Perceived risk has a negative effect on consumer intention to use contactless credit cards for payment.

Consumers both consciously and unconsciously perceive risks when evaluating transactions (Featherman and Pavlou, 2003). When a person trusts an object (e.g., a store, a channel, a brand or a payment method), feelings of confidence and security arise within that person towards the object (Rempel et al., 1985). Trust, consequently, can reduce consumers' perceptions of risk (Chiou and Shen, 2012).

As contactless credit cards are a new type of payment method, they may increase customers' sense of uncertainty and anxiety (i.e., perceived risk). Risk perceptions can negatively influence consumers' perceptions of usefulness (Featherman and Pavlou, 2003). The more a person trusts the innovation, the less they will perceive risks associated with it. Perceived risk, in turn, negatively influences usefulness (van der Heijden et al., 2003). Thus, the following hypotheses are proposed:

H10. Consumers' trust has a negative effect on perceived risk of using contactless credit cards for payment.

H11. Perceived risk has a negative effect on the perceived usefulness of using contactless credit cards for payment.

Personal innovativeness refers to the willingness of an individual to embrace change and try out new information technologies (Agarwal and Prasad, 1998). Highly innovative individuals tend to take more risks and have more confidence in their capability to handle the uncertainty associated with new technology ( $\mathrm{Lu}$ et al., 2005). These individuals, therefore, will have greater intentions to adopt a new information technology. Some studies have also found that personal innovativeness has a direct effect on the adoption of wireless services (Lu et al., 2008), advanced mobile services (López-Nicolás et al., 2008), and mobile payment services (Yang et al., 2012). Therefore, we include personal innovativeness in the research model. The following hypothesis is proposed:

H12. Personal innovativeness has a positive effect on consumer intention to use contactless credit cards for payment.

Involvement relates to the perceived relevance of an object based on an individual's needs, values, and interests (Zaichkowsky, 1985). Consumers with high involvement always display extensive information search behaviours that furnish them with deep knowledge about a target object (Chaudhuri, 2000) and, in consequence, a high level of acceptance (Shim et al., 2001). Many researchers find that involvement is an important predictor of adoption of innovative transaction methods (Kamarulzman, 2007; Lian and Lin, 2008). Therefore, we include consumer involvement in the research model. The following hypothesis is proposed: 
H13. Consumers' involvement has a positive effect on their intention to use contactless credit cards for payment.

\section{Research model and research methodology}

\subsection{Research model}

Based on the foregoing discussion in Section 2, the research model was proposed as shown in Figure 2. There are nine constructs in the research model, which includes compatibility, perceived behavioural control, trust, personal innovativeness, and consumer involvement as independent variables, perceived usefulness, PEOU, and perceived risk as mediating variables, and consumers' intention to use as the dependent variable. The signs show the hypothesised positive or negative associations among the constructs.

In order to deeply understand what influences consumer intention to use contactless credit cards for payment, the research model not only explores the direct antecedents of consumer intention, but it also analyses the inter-relationships among these antecedents.

Figure 2 The research model

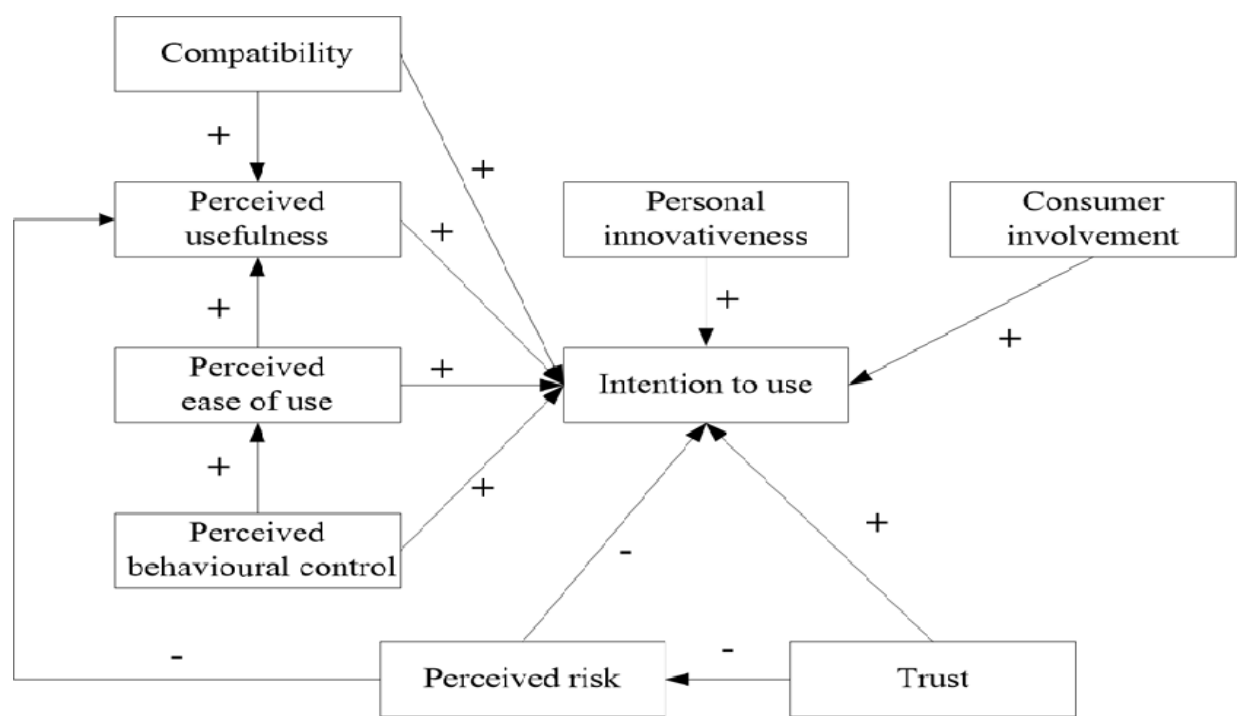

\subsection{Construct measures}

Measures of the principal constructs were drawn from existing instruments and modified to fit the context of contactless credit cards use. Items for the perceived usefulness (PI) and PEOU were adapted from previous applications of TAM (Chiou and Shen, 2012). The items for measuring compatibility (CM) and personal innovativeness (PI) constructs were adapted from Agarwal and Prasad (1998). Three items pertaining to perceived behavioural control (PBC) and two items related to consumer intention (IU) were taken from Taylor and Todd (1995). Three items relating to the trust (TR) construct were adapted from Chiou (2004) and Liebana-Cabanillas et al. (2014a). The scale of perceived 
risk (PR) was based on Wu and Wang (2005). The measures for consumer involvement (CI) were captured using three items derived from Zaichkowsky (1985). All items were measured using a five-point Likert-type scale with anchors from ' $(-2)$ strongly disagree' to "(2) strongly agree". Table 2 summarises the measurement items of all the constructs in this study.

Table 2 Measurement items used in this study

\begin{tabular}{|c|c|}
\hline Construct & Items \\
\hline \multirow[t]{4}{*}{$\begin{array}{l}\text { Perceived usefulness } \\
\text { (PU) }\end{array}$} & $\begin{array}{l}\text { 1. Using a contactless credit card enables me to make payments more } \\
\text { quickly }\end{array}$ \\
\hline & $\begin{array}{l}2 \text { Using a contactless credit card improves my payment performance } \\
\text { while conducting transactions }\end{array}$ \\
\hline & $\begin{array}{l}\text { 3. Using a contactless credit card makes it easier for me to conduct } \\
\text { payment transactions }\end{array}$ \\
\hline & $\begin{array}{l}\text { 4. I think using a contactless credit card is useful when conducting } \\
\text { my payment transactions }\end{array}$ \\
\hline \multirow{3}{*}{$\begin{array}{l}\text { Perceived ease of use } \\
\text { (PEOU) }\end{array}$} & 1. I think using a contactless credit card is easy \\
\hline & 2. Learning to operate a contactless credit card is easy for me \\
\hline & $\begin{array}{l}\text { 3. My interaction with the contactless credit card is clear and } \\
\text { understandable }\end{array}$ \\
\hline \multirow[t]{3}{*}{ Compatibility (CM) } & $\begin{array}{l}\text { 1. I think that using a contactless credit card fits well with the } \\
\text { payment-style I like }\end{array}$ \\
\hline & $\begin{array}{l}\text { 2. Using a contactless credit card fits well with the way I conduct } \\
\text { payment transactions }\end{array}$ \\
\hline & $\begin{array}{l}\text { 3. Using a contactless credit card is compatible with my transaction } \\
\text { situation }\end{array}$ \\
\hline \multirow{3}{*}{$\begin{array}{l}\text { Perceived behavioural } \\
\text { control (PBC) }\end{array}$} & 1. I would have the ability to use a contactless credit card \\
\hline & $\begin{array}{l}\text { 2. Using a contactless credit card would be entirely within my } \\
\text { control }\end{array}$ \\
\hline & $\begin{array}{l}\text { 3. I would have the knowledge and resources to make use of a } \\
\text { contactless credit card }\end{array}$ \\
\hline \multirow[t]{3}{*}{ Trust (TR) } & 1. I think that the issuers of contactless credit cards are honest \\
\hline & 2. I think that the issuers of contactless credit cards are responsible \\
\hline & 3. I think that the issuers of contactless credit cards are professional \\
\hline \multirow[t]{3}{*}{ Perceived risk (PR) } & $\begin{array}{l}\text { 1. I think that using a contactless credit card for payment transactions } \\
\text { has potential risk }\end{array}$ \\
\hline & $\begin{array}{l}\text { 2. I think using a contactless credit card within the scope } \\
\text { of merchandise service has potential risk }\end{array}$ \\
\hline & 3. I think using a contactless credit card puts my privacy at risk \\
\hline \multirow{3}{*}{$\begin{array}{l}\text { Personal innovation } \\
(\mathrm{PI})\end{array}$} & 1. I like to try out new information technologies \\
\hline & 2. I am unhesitant to try out new information technologies \\
\hline & 3. I like to experiment with new information technologies \\
\hline
\end{tabular}


Table 2 Measurement items used in this study (continued)

\begin{tabular}{ll}
\hline Construct & Items \\
\hline Consumer involvement & 1. I am interested in receiving information about contactless credit \\
(CI) & cards \\
& $\begin{array}{l}\text { 2. I am interested in reading related papers about contactless credit } \\
\text { cards } \\
\text { 3. I have compared characteristics among contactless credit cards } \\
\text { issued by different issuers } \\
\text { 1. I intend to use a contactless credit card for payment transactions } \\
\text { 2. I plan to use a contactless credit card for payment transactions in } \\
\text { the future }\end{array}$ \\
\hline
\end{tabular}

\subsection{Data collection and sample characteristics}

Data for this study were collected using a questionnaire survey in Taiwan. The subjects were individuals eligible to apply for a credit card. Due to the lack of a suitable sampling frame that would be representative of the population, the purposive accidental sampling technique was used. The researchers selected a sample from passengers and customers at train stations and department stores who were eligible to apply for a credit card or actually had credit card use experiences. These qualified passersby were introduced to the research purpose by researchers and invited to completely fill in the questionnaires. If they agreed to participate in the survey, every respondent was given an NT 50-dollar incentive. The questionnaire was composed of three parts. The first part is to describe the research purpose and introduce contactless credit cards. The second part contains 27 items that measure the nine constructs in the research model. The items are shown in Table 2. The third part includes questions regarding participants' demographics, socio-economic status, and experiences using credit cards.

A total of 250 questionnaires were received. Of these responses, 4 were considered incomplete and were discarded. This left 246 valid responses for analysis. The sample was almost equally split between male (48.8\%) and female. Almost all of the respondents (99.2\%) already had credit cards (average per subject was 2.71). Table 3 presents the respondents' profile.

\section{Data analysis and results}

The structural equation modelling (SEM) approach was used to analyse the data. This study followed the two-phased procedure suggested by Anderson and Gerbing (1988). First, the measurement model was estimated to test the overall fit, reliability, and validity. Second, the hypotheses were tested using the structural model. The LISREL 8.51 software was used for this purpose.

\subsection{Measurement model}

Five common indices were used to assess the fitness between the data and the hypothesised measurement model. These indexes are the ratio of $\chi^{2}$ to the degrees of freedom, goodness-of-fit (GFI), adjusted goodness-of-fit index (AGFI), parsimony 
goodness-of-fit (PGFI), and root mean square error of approximation (RMSEA). As shown in Table 4, all the model fit indices exceeded their respective common acceptance levels suggested by Hair et al. (2010) and Hadjistavropoulos et al. (1999), thus demonstrating that the measurement model exhibited a good fit with the data collected.

Table 3 Respondent profiles

\begin{tabular}{lc}
\hline Demographics & Frequency \\
\hline Gender & \\
Male & $48.8 \%$ \\
Female & $51.2 \%$ \\
Age & \\
Less than 30 & $48.2 \%$ \\
$31-40$ & $32.1 \%$ \\
$41-50$ & $15.5 \%$ \\
Over 50 & $3.3 \%$ \\
Monthly income (NT\$) & \\
Less than 10,000 & $11.8 \%$ \\
$10,001-30,000$ & $30.5 \%$ \\
$30,001-60,000$ & $46.3 \%$ \\
Over 60,001 & $11.4 \%$ \\
Already had credit cards & \\
Yes & $99.2 \%$ \\
No & $0.8 \%$ \\
Average number of credit cards per respondent & 2.79 \\
\hline
\end{tabular}

Table 4 Fit indices for measure model

\begin{tabular}{lcc}
\hline Fit indices & Criteria & Model \\
\hline$\chi^{2} / \mathrm{df}$ & $<3$ & 1.51 \\
GFI & $>0.85$ & 0.88 \\
AGFI & $>0.80$ & 0.85 \\
PGFI & $>0.50$ & 0.70 \\
RMSEA & $<0.05$ & 0.04 \\
\hline
\end{tabular}

The reliability and validity of the measurement model was carefully examined. The composite reliability shows the degree to which the measurement items depict a common construct. Table 5 shows that the composite reliabilities for all the constructs in the measurement model range from 0.87 to 0.95 . These all exceeded the recommended value of 0.7 and this supports the reliability of the measurement model (Hair et al., 2010). The convergent validity was evaluated by examining the factor loadings and the average variance extracted (AVE). The results in Table 5 show that the factor loadings of the measurement items in the model are greater than the recommended value of 0.7 . All AVE values of constructs were above the recommended 0.5 levels. These recommended values 
are based on the suggestions of Hair et al. (2010). These results support our claim of adequate convergent validity.

For each construct, the AVE value is greater than the squared correlations with other constructs in the measurement model and this indicates good discriminant validity (Fornell and Larcker, 1981).

Table 5 Construct reliabilities and validities

\begin{tabular}{|c|c|c|c|c|}
\hline Constructs & Items & Factor loading & Composite reliability & $A V E$ \\
\hline \multirow[t]{4}{*}{ PU } & PU1 & 0.88 & 0.92 & 0.75 \\
\hline & PU2 & 0.88 & & \\
\hline & PU3 & 0.87 & & \\
\hline & PU4 & 0.83 & & \\
\hline \multirow[t]{3}{*}{ PEOU } & PEOU1 & 0.88 & 0.91 & 0.77 \\
\hline & PEOU2 & 0.88 & & \\
\hline & PEOU3 & 0.87 & & \\
\hline \multirow[t]{3}{*}{$\mathrm{CM}$} & CM1 & 0.89 & 0.87 & 0.70 \\
\hline & $\mathrm{CM} 2$ & 0.86 & & \\
\hline & CM3 & 0.75 & & \\
\hline \multirow[t]{3}{*}{$\mathrm{PBC}$} & $\mathrm{PBC} 1$ & 0.84 & 0.91 & 0.76 \\
\hline & PBC2 & 0.89 & & \\
\hline & PBC3 & 0.89 & & \\
\hline \multirow[t]{3}{*}{ TR } & TR1 & 0.92 & 0.93 & 0.83 \\
\hline & TR2 & 0.91 & & \\
\hline & TR3 & 0.90 & & \\
\hline \multirow[t]{3}{*}{ PR } & PR1 & 0.94 & 0.95 & 0.85 \\
\hline & PR2 & 0.94 & & \\
\hline & PR3 & 0.88 & & \\
\hline \multirow[t]{3}{*}{ PI } & PI1 & 0.91 & 0.93 & 0.82 \\
\hline & PI2 & 0.91 & & \\
\hline & PI3 & 0.90 & & \\
\hline \multirow[t]{3}{*}{ CI } & CI1 & 0.92 & 0.90 & 0.75 \\
\hline & $\mathrm{CI} 2$ & 0.88 & & \\
\hline & $\mathrm{CI} 3$ & 0.79 & & \\
\hline \multirow[t]{2}{*}{ IU } & IU1 & 0.95 & 0.94 & 0.89 \\
\hline & IU2 & 0.94 & & \\
\hline
\end{tabular}

\subsection{Structural model}

The hypotheses were tested by examining the structural model. Figure 3 shows the standard path coefficients, their significance for the structural model, and the coefficients of the determinant $\left(R^{2}\right)$ for each of the endogenous constructs. The standardised path coefficient indicates the strength of the relationships between the independent and 
dependent variables. The $R^{2}$ value represents the amount of a dependent variable's variance explained by the independent variables (Hair et al., 2010). Table 6 summarises the results of the hypotheses testing.

Figure 3 Hypotheses testing results

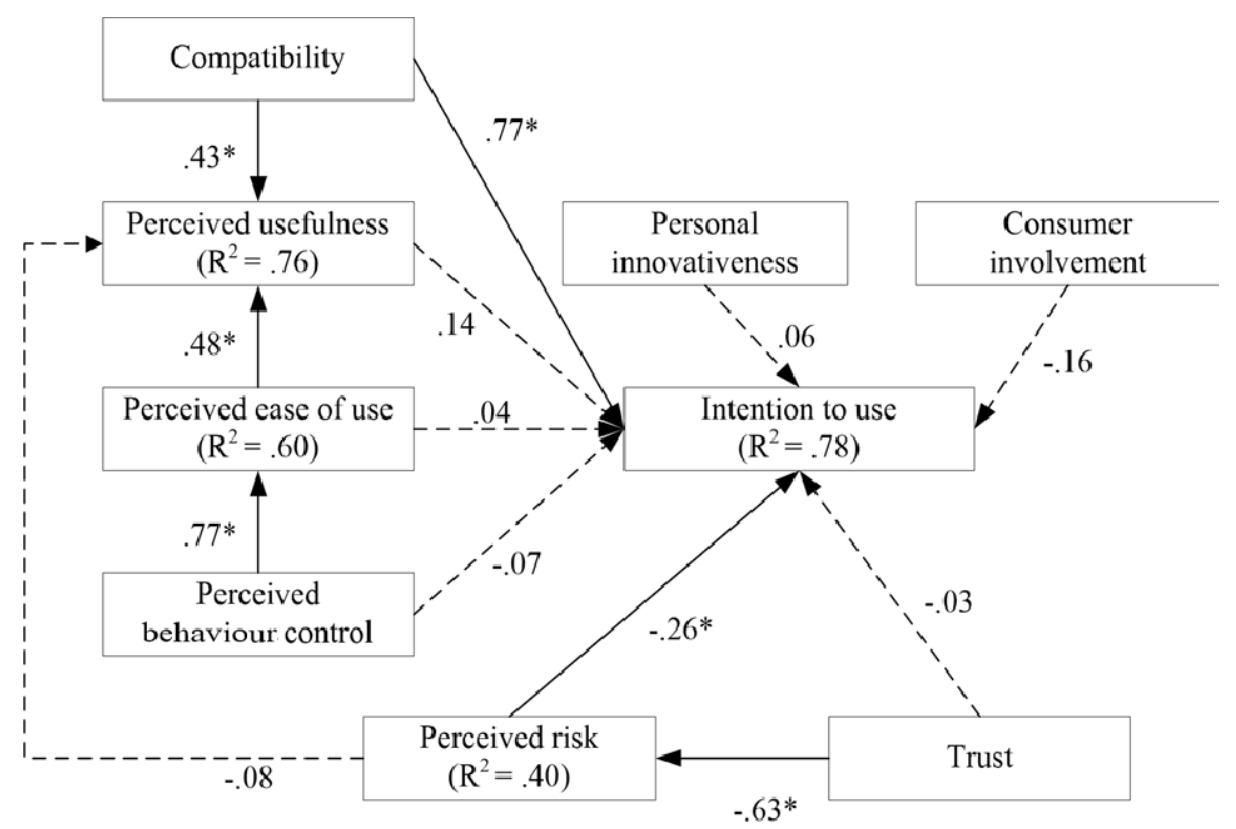

Path significance: ${ }^{*} p<0.05$.

Dotted lines represent non-significant paths.

Table 6 Summary of hypotheses testing results

\begin{tabular}{lc}
\hline Hypotheses & Support \\
\hline $\mathrm{H} 1: \mathrm{PU} \rightarrow \mathrm{IU}$ & No \\
$\mathrm{H} 2: \mathrm{PEOU} \rightarrow \mathrm{IU}$ & No \\
$\mathrm{H} 3: \mathrm{CM} \rightarrow \mathrm{IU}$ & Yes \\
$\mathrm{H} 4: \mathrm{PEOU} \rightarrow \mathrm{PU}$ & Yes \\
$\mathrm{H} 5: \mathrm{CM} \rightarrow \mathrm{PU}$ & Yes \\
$\mathrm{H} 6: \mathrm{PBC} \rightarrow \mathrm{PEOU}$ & Yes \\
$\mathrm{H} 7: \mathrm{PBC} \rightarrow \mathrm{IU}$ & No \\
$\mathrm{H} 8: \mathrm{TR} \rightarrow \mathrm{IU}$ & No \\
$\mathrm{H} 9: \mathrm{PR} \rightarrow \mathrm{IU}$ & Yes \\
$\mathrm{H} 10: \mathrm{TR} \rightarrow \mathrm{PR}$ & Yes \\
$\mathrm{H} 11: \mathrm{PR} \rightarrow \mathrm{PU}$ & No \\
$\mathrm{H} 12: \mathrm{PI} \rightarrow \mathrm{IU}$ & No \\
$\mathrm{H} 13: \mathrm{CI} \rightarrow \mathrm{IU}$ & No \\
\hline
\end{tabular}


The model explains $78 \%$ of the variation in consumer intention to use contactless credit cards for payment. However, only perceived compatibility and perceived risk are found to have significant influences on consumer intention to use contactless credit cards for payment (i.e., hypotheses 3 and 9 are supported). The results also show that PEOU and compatibility are significant predictors of perceived usefulness, while trust has a significant and negative effect on perceived risk (i.e., hypotheses 4, 5, 6, and 10 are supported).

\section{Discussion}

The empirical findings show that compatibility and perceived risk are the only significant determinants of consumer intention to use contactless credit cards for payment. Compatibility has the strongest direct effect on the consumers' use intention. Compatibility reflects the level of consumer perceptions towards the reconcilability of an innovation with their existing practices, experiences, habits, and preferences. When consumers regard an innovative payment instrument (e.g., contactless credit card) as compatible with their habits and practices, it is likely that it will create a favourable impression in their minds. A positive impression may facilitate positive consumer intention to use the innovative instrument for payment. Therefore, perceived compatibility positively influences consumers' intention to use contactless credit cards for payment. This finding is important to practitioners. People that use credit cards for payment and have the habit of using wireless devices may be early adopters of contactless credit cards. Practitioners can use marketing strategies to attract these people to apply for and use contactless credit cards for payment.

Perceived risk significantly inhibits consumers' intention to use contactless credit cards for payment. Despite the fact that contactless credit cards can improve security and reduce risk (Smart Payment Association, 2016; Wikipedia, 2016), consumers still think that using contactless credit cards for payment may be risky, unsafe, and uncertain (Osborne, 2015, 2016). According to the work of Singh et al. (2004), the potential security problems include:

- $\quad$ The hijacking of data by a party not involved in a credit card transaction: This can occur when information is capture during data transmission between a contactless card and a contactless card reader.

- $\quad$ Pick-pocketing of data: A fake device activates and reads the contactless card without the cardholder's awareness.

- A man in the middle attack: An exchange between a contactless card and an allowed card reader is unknowingly intercepted by a third and unauthorised device in the transaction process.

By overcoming security problems and increasing consumer awareness of the safety factors inherent in contactless credit cards, firms may be able to increase customers' intention to use them for payment.

Contrary to the assertion of TAM, perceived usefulness and PEOU were not found to have significant effects on consumer intention to use contactless credit cards for payment. The findings are similar to the works of van der Heijden et al. (2003) and Chiou and Shen (2012). Since payment using a contactless credit card only saves about 12-14 s compared 
to traditional credit card transactions, consumers may perceive the overall time savings to be negligible (Wang, 2008). Therefore, consumer perceptions of the relative advantage derived from using contactless credit cards are not powerful enough to enhance consumer intention to use them for payment. In terms of PEOU, Wu and Wang (2005) argue that when potential users have little or no direct experiences with the innovation, this factor is relevant. Consumers have many opportunities to use contactless IC cards in their everyday life (for example to unlock car doors or pay for mass transportation). Therefore, they do not regard the use of contactless credit cards for payment as particularly difficult. Hence, PEOU has no significant influence on consumer intention to use contactless credit cards for payment.

Interestingly, while trust does not significantly affect consumers' intention to use contactless credit cards for payment, it does significantly decrease consumers' perceived risk. Since consumers already trust the issuers of traditional credit cards, who also provide contactless cards, this may explain why the trust factor is not significant. In this case, consumers do not need to reevaluate their trust of issuers when they consider whether or not to use contactless credit cards for payments.

Personal innovativeness and consumer involvement do not significantly affect the consumer intention to use contactless credit cards for payment. Possibly, these two factors are important determinants of consumer acceptance toward hedonic goods, but they have no significant effects on consumer acceptance toward utilitarian goods (such as contactless credit cards). Therefore, consumers are mainly concerned with the transaction safety and effectiveness of using contactless credit cards. Future research is needed to explore how personal innovativeness and involvement relate to utilitarian and hedonic values in adoption.

Perceived behavioural control has no direct, significant effect on the consumer intention to use contactless credit cards for payment. The reason may be that perceived behavioural control is a hygiene factor (Herzberg, 1959) or a threshold variable (van der Heijden et al., 2003). When consumers have low perceived behavioural control towards the use of contactless credit cards, the perceptions may negatively affect their use intention. That is, low perceived behaviour control may be an obstacle to customers' intention to use. However, perceived behavioural control may not contribute to customers' positive intentions to use this payment method.

As expected, PEOU and perceived compatibility significantly influence perceived usefulness, and perceived behavioural control has a significant and positive influence on customers' PEOU. These findings are consistent with the results reported in prior adoption studies (e.g., Fu et al., 2006; Wu and Wang, 2005; Yi et al., 2006). This suggests that card issuers can focus efforts on enhancing facilitating mechanisms and reducing constraints to help consumers easily use contactless credit cards for payment. In addition, when consumers feel that it is difficult to use contactless credit cards for payment or that the use is inconsistent with their payment practices, then they will have a higher cognitive burden.

Surprisingly, the data did not support any significant effects of perceived risk on consumers' perceptions of usefulness. One possible explanation is that most advantages from using contactless credit cards pertain to payment efficiency rather than effectiveness. For example, payment speed, payment performance, and transaction convenience are included in the measure. Therefore, the relationship between perceived usefulness and perceived risk is insignificant. Other studies have also found that 
perceived risk is not directly associated with perceived usefulness in the mobile commerce context (e.g., Chen, 2008; Wu and Wang, 2005 and Zhang et al., 2012).

\section{Implications}

\subsection{Implications for research}

This study contributes to our understanding of consumer intention to pay by contactless credit cards, which has been relatively understudied in the past. The findings of this study provide some important research implications.

First, TAM may not hold well across all technologies and use situations. TAM is based on the assumption that a new technology is introduced to replace an old one (Mallat, 2007). However, the payment method of contactless credit cards has not completely replaced but merely complements the existing payment instruments in some transaction situations. Therefore, the significant determinants of use intention may be different.

Second, the main purpose of using contactless credit cards is for payments which involve monetary transactions. The purpose of using contactless credit cards is different from that of using general information technologies. Therefore, the factors that determine use intention may be different. Because of the natures of payment and monetary transactions, risk and compatibility issues are always important concerns for consumers.

Finally, the research findings enhance our understanding of what determines consumers' intention to use contactless credit cards for payment. For the use of a payment instrument, consumers consider not only the technology-related issue (i.e., risk) but also the individual issue (i.e., compatibility). The technology and individual factors jointly determine the consumer intentions to use this payment instrument. The research findings add a deeper understanding to the literature of contactless (mobile) payment use.

\subsection{Implications for practitioners}

The findings of this study provide several important practical implications for the promotion of contactless credit cards. The compatibility and risk factors were found to have direct influences on consumer intention to pay by contactless credit cards. These findings will allow practitioners to efficiently and effectively develop strategies to better meet consumer concerns.

First, practitioners should improve consumer perceptions of compatibility associated with using contactless credit cards. Since contactless credit cards are a new type of payment instrument, consumers may be unfamiliar and feel strange. Therefore, perceived compatibility is the important factor affecting intention to use contactless credit cards for payment. Practitioners should design and develop transaction situations, payment styles and ways of using contactless credit cards that fit well with consumer preferences and habits.

Second, practitioners need to develop effective strategies to assist consumers to reduce the level of perceived risk of using contactless credit cards. As contactless credit cards are an innovative type of payment instrument, they may increase customers' sense of uncertainty and anxiety. Thus, transaction security certificates, robust protection mechanisms, assurance procedures, and secure commitment may enhance consumers' 
confidence in using contactless credit cards. This study also finds that trust can lower perceived risk. Thus, strategies for enhancing consumer trust can also reduce consumerperceived risk. Practitioners need to improve consumer trust in the issuers of contactless credit cards.

\section{Conclusion}

Firms have invested significant resources to develop contactless payment instruments. It is important, therefore, to understand consumers' reactions to and willingness to engage with this innovative payment method. This study developed and tested a model to analyse and understand consumer intention to use contactless credit cards as the payment instrument. The model was evaluated using survey data from 246 potential users that were eligible for credit card applications and showed a good explanatory power $\left(R^{2}=0.78\right)$ for consumer intention to use contactless credit cards for payment. The results not only offer new insights for payment method adoption but also help practitioners understand why consumers accept or resist using contactless credit cards for payment. The major contributions of this work are summarised as follows:

- Compatibility and perceived risk are the main determinants that affect consumer intention to pay by contactless credit cards. Trust in the issuers of contactless credit cards can reduce consumers' perceived risk.

- The two main constructs in TAM (i.e., perceived usefulness and PEOU) do not have any significant direct effects on consumer intention to pay using contactless credit cards. The applicability of TAM is not always supported in all technology acceptance contexts.

- This study also supports prior research findings in that we find perceived behavioural control has a positive effect on PEOU, and PEOU and compatibility influence perceived usefulness.

- This study finds that some variables have no significant direct effects on customer intention to pay using contactless credit cards. These variables include personal innovativeness, consumer involvement, and perceived behavioural control.

This study is bound to a number of limitations and a number of these represent opportunities for future research. First, the findings draw on data sampled from consumers in Taiwan. Further research could draw useful samples from other settings to validate and extend our findings.

Second, this study employed a snapshot research approach. The implications and conclusions drawn from this study were based on the cross-sectional data. Therefore, future research can adopt a longitudinal research design that can enhance our understanding of the formation of contactless credit cards usage over time.

Third, the development of payment by contactless credit cards is in the early stage of diffusion. The availability of access to contactless payment systems is not very widespread at present. Insufficient convenience and unpopularity may lower consumer intention to use these cards. This study could be replicated when contactless payment is more mature. 
Fourth, there are two main types of contactless credit cards. One is the extension of traditional electronic magnetic cards and the other is NFC-enabled mobile phones. Consumers may have different concerns when they pay by different types of contactless credit cards. Future studies could analyse whether different types of contactless credit cards are associated with different determinants of user intention.

Finally, the sample in this study also incorporates the respondents that have no actual usage experiences with contactless credit cards. This is not a serious limitation since the objective of this study is to explore what factors affect consumers' future intention to pay using contactless credit cards. Therefore, the sample in this study can include the consumers that have no use experiences about contactless credit cards. Many adoption intention studies also draw on samples that include potential users with no real experiences with a particular technology. In addition, we took considerable care to ensure the questionnaire made clear what contactless credit cards are.

\section{Acknowledgements}

The authors would like to thank Dr. W-C. Tai and Dr. C-C. Chiou for assisting with data collection and providing suggestions. This work was partially supported by the Minster of Science and Technology in Taiwan under the grant MOST 105-2511-S-260-004-MY3.

\section{References}

Agarwal, R. and Prasad, J. (1998) 'A conceptual and operational definition of personal innovativeness in the domain of information technology', Information Systems Research, Vol. 9, No. 2, pp.204-215.

Ajzen, I. (1991) 'The theory of planned behavior', Organizational Behavior and Human Decision Processes, Vol. 50, No. 2, pp.179-211.

Anderson, J. and Gerbing, J. (1988) 'Structural equation modeling in practice: a review and recommended two-step approach', Psychological Bulletin, Vol. 103, No. 3, pp.411-423.

Bhatti, T. (2007) 'Exploring factors influencing the adoption of mobile commerce', Journal of Internet Banking and Commerce, Vol. 12, No. 3, pp.1-13.

Card Technology Today (2006) 'Wells Fargo announces contactless card rollout', Card Technology Today, Vol. 18, No. 6, pp.3, 4.

Castaneda, J.A., Frías, D.M. and Rodríguez, M.A. (2009) 'Antecedents of internet acceptance and use as an information source by tourists', Online Information Review, Vol. 33, No. 3, pp.548-567.

Cha, J. (2011) 'Exploring the Internet as a unique shopping channel to sell both real and virtual items: a comparison of factors affecting purchase intention and consumer characteristics', ,Journal of Electronic Commerce Research, Vol. 12, No. 2, pp.115-132.

Chaudhuri, A.A. (2000) 'Macro analysis of the relationship of product involvement and information search: the role of risk', Journal of Marketing Theory and Practice, Vol. 8, No. 1, pp.1-15.

Chen, L.D. (2008) 'A model of consumer acceptance of mobile payment', International Journal of Mobile Communications, Vol. 6, No. 1, pp.32-52.

Chiou, J.S. (2004) 'The antecedents of consumers' loyalty toward internet service providers', Information and Management, Vol. 41, No. 6, pp.685-695. 
Chiou, J.S. and Shen, C.C. (2012) 'The antecedents of online financial service adoption: the impact of physical banking services on internet banking acceptance', Behaviour and Information Technology, Vol. 31, No. 9, pp.859-871.

Collinson, P. (2015) Contactless Payments: Should Banks Force Us to Use Them?, http://www. theguardian.com/money/2015/jan/17/contactless-payments-banks-force-us

Davis, F.D. (1989) 'Perceived usefulness, perceived ease of use and user acceptance of information technologies', MIS Quarterly, Vol. 13, No. 3, pp.319-340.

Dobschuetz, K. (2015) How is Contactless Payment Marketed?, http://www.biggroup.co.uk/ en/blog/2015/apr/contactless.

Doney, P.M. and Cannon, J.P. (1997) 'An examination of the nature of trust in buyer-seller relationship', Journal of Marketing, Vol. 61, No. 2, pp.35-51.

Featherman, M.S. and Pavlou, P.A. (2003) 'Predicting e-services adoption: a perceived risk facets perspective', International Journal of Human-Computer Studies, Vol. 59, No. 4, pp.451-474.

Fornell, C. and Larcker, D.F. (1981) 'Evaluating structural equation models with unobservable variables and measurement error', Journal of Marketing Research, Vol. 18, No. 1, pp.39-50.

Fu, J., Farn, C. and Chao, W. (2006) 'Acceptance of electronic tax filing: a study of taxpayer intentions', Information and Management, Vol. 43, No. 1, pp.109-126.

Fung, B., Huynh, K.P. and Stuber, G. (2015) 'The use of cash in Canada', Bank of Canada Review, Spring, pp.45-56.

Hadjistavropoulos, H.D., Frombach, I.K. and Asmundson, G.J.G. (1999) ''Exploratory and confirmatory factor analytic investigations of the illness attitudes scale in a nonclinical sample', Behaviour Research and Therapy, Vol. 37, No. 7, pp.671-684.

Hair, J.F., Black, W.C., Babin, B.J. and Anderson, R.E. (2010) Multivariate Data Analysis: A Global Perspective, 7th ed., Prentice Hall, NJ.

Henry, C.S., Huynh, K.P. and Shen, Q.R. (2015) 2013 Methods-of-Payment Survey Results, Bank of Canada Discussion Paper.

Herzberg, F. (1959) The Motivation to Work, John Wiley, New York.

Hewgill, N. (2008) 'Contactless comes of age on Switzerland', Card Technology Today, Vol. 20, No. 4, p.10.

Kamarulzman, Y. (2007) 'Adoption of travel E-shopping in the UK', international', Journal of Retail and Distribution Management, Vol. 35, No. 9, pp.703-719.

Kemp, R. (2013) 'Mobile payments: current and emerging regulatory and contracting issues', Computer Law and Security Review, Vol. 29, No. 2, pp.175-179.

Kim, C., Mirusmonov, M. and Lee, I. (2010) 'An empirical examination of factors influencing the intention to use mobile payment', Computers in Human Behavior, Vol. 26, No. 3, pp.310-322.

Kolodinsky, J.M., Hogarth, J.M. and Hilgert, M.A. (2004) 'The adoption of electronic banking technologies by US consumers', The International Journal of Bank Marketing, Vol. 22, No. 4, pp.238-259.

Lederer, A.L., Maupin, D.J., Sena, M.P. and Zhuang, Y. (2000) 'The technology acceptance model and the world wide web', Decision Support Systems, Vol. 29, No. 3, pp.269-282.

Legris, P., Ingham, J. and Collerette, P. (2003) "Why do people use information technology? a critical review of the technology acceptance model', Information and Management, Vol. 40, No. 3, pp.191-204.

Leong, L., Hew, T., Tan, G.W. and Ooi, K. (2013) 'Predicting the determinants of the NFC-enabled mobile credit card acceptance: a neural networks approach', Experts Systems with Applications, Vol. 40, No. 12, pp.5604-5620.

Lian, J. and Lin, T. (2008) 'Effects of consumer characteristics on their acceptance of online shopping: comparisons among different product types', Computers in Human Behavior, Vol. 24, No. 1, pp.48-65. 
Liebana-Cabanillas, F., Sanchez-Fernandez, J. and Munoz-Leiva, F. (2014a) 'Antecedents of the adoption of the new mobile payment systems: the moderating effect of age', Computers in Human Behavior, Vol. 35, pp.464-478.

Liebana-Cabanillas, F., Sanchez-Fernandez, J. and Munoz-Leiva, F. (2014b) 'The moderating effect of experience in the adoption of mobile payment tools in virtual social networks: the mpayment acceptance model in virtual social networks (MPAM-VSN)', International Journal of Information Management, Vol. 34, No. 2, pp.151-166.

Lin, C.W., Hsu, Y.C. and Lin, C.Y. (2017) 'User perception, intention and attitude on mobile advertising', International Journal of Mobile Communications, Vol. 15, No. 1, pp.104-117.

Lin, Y.M. and Shih, D.H. (2008) 'Deconstructing mobile commerce service with continuance intention', International Journal of Mobile Communications, Vol. 6, No. 1, pp.67-87.

Lomax, C. (2005) 'The future is contactless', Card Technology Today, Vol. 17, No. 10, pp.10, 11.

López-Nicolás, C., Molina-Castello, F.J. and Bouwman, H. (2008) 'An assessment of advanced mobile services acceptance: contributions from TAM and diffusion theory models', Information and Management, Vol. 45, No. 6, pp.359-364.

Lu, J., Liu, C., Yu, C. and Wang, K. (2008) 'Determinants of accepting wireless mobile data services in China', Information and Management, Vol. 45, No. 1, pp.52-64.

Lu, J., Yao, J. and Yu, C. (2005) 'Personal innovativeness, social influences and adoption of wireless internet services via mobile technology', The Journal of Strategic Information Systems, Vol. 14, No. 3, pp.245-268.

Lu, Y., Zhou, T. and Wang, B. (2009) 'Exploring Chinese users' acceptance of instant messaging using the theory of planned behavior, the technology acceptance model and the flow theory', Computers in Human Behavior, Vol. 25, No. 1, pp.29-39.

Mallat, N. (2007) 'Exploring consumer adoption of mobile payments-a qualitative study', Journal of Strategic Information Systems, Vol. 16, No. 4, pp.413-432.

Moon, J.W. and Kim, Y.G. (2001) 'Extending the TAM for a world-wide-web context', Information and Management, Vol. 38, No. 4, pp.217-230.

Moore, G.C. and Benbasat, I. (1991) 'Development of an instrument to measure the perceptions of adopting an information technology innovation', Information Systems Research, Vol. 2, No. 3 , pp.192-222.

Olschewski, M., Renken, U.B., Billinger, A.C. and Moslein, K.M. (2013) 'Are you ready to use? assessing the meaning of social influence and technology readiness in collaboration adoption', paper presented at The 46th Hawaii International Conference on System Sciences.

Ondrus, J. and Pigneur, Y. (2009) 'Near field communication: an assessment for future payment systems', Information Systems and e-Business Management, Vol. 7, No. 3, pp.347-361.

Osborne, H. (2015) Spending using Contactless Cards Trebles in 2014, http://www.theguardian. com/money/2015/feb/06/contactless-cards-treble-2014

Osborne, H. (2016) Contactless Payments used for 1 bn UK Purchases in 2015, http://www. theguardian.com/money/2016/feb/26/contactless-cards-purchases-spending

Pavlou, P.A. (2003) 'Consumer acceptance of electronic commerce: integrating trust and perceived risk with the technology acceptance model', International Journal of Electronic Commerce, Vol. 7, No. 3, pp.101-134.

Rempel, J.K., Holmes, J.G. and Zanna, M.P. (1985) 'Trust in close relationships', Journal of Personality and Social Psychology, Vol. 49, No. 1, pp.95-112.

RFi Media Centre (2016) Contactless Transactions Gaining traction Amongst UK Consumers, UK Retail Banker, March.

Rigopoulou, I.D. and Chaniotakis, I.E. (2017) 'An extended technology acceptance model for predicting smartphone adoption among young consumers in Greece', International Journal of Mobile Communications, Vol. 15, No. 4, pp.372-386.

Rogers, E.M. (1983) Diffusion of Innovations, 3rd ed, The Free Press, New York. 
Rugimbana, R. (1995) 'Predicting automated teller machine usage: the relative importance of perceptual and demographic factors', International Journal of Bank Marketing, Vol. 13, No. 4, pp.26-32.

Sathye, M. (1999) 'Adoption of internet banking by Australian consumers: an empirical investigation', International Journal of Bank Marketing, Vol. 17, No. 7, pp.324-334.

Schierz, P.G., Schilke, O. and Wirtz, B.W. (2010) 'Understanding consumer acceptance of mobile payment services: an empirical analysis', Electronic Commerce Research and Applications, Vol. 9, No. 3, pp.209-216.

Shih, Y.W. (2011) 'Facilitators and benefits of using mobile entertainment services', International Journal of Mobile Communications, Vol. 9, No. 5, pp.458-476.

Shim, S., Eastlick, M.A., Lotz, S.L. and Warrington, P. (2001) 'An on-line prepurchase intentions model: the role of intention to search', Journal of Retailing, Vol. 77, No. 3, pp.397-416.

Singh, S.J., Trudy, H. and Carole, O. (2004) Methods for Performing Transactions in a Wireless Environment, http://www.freepatentsonline.com/20040068472.html

Smart Payment Association (2016) An Overview of Contactless Payment Benefits and Worldwide Deployments, $\quad$ http://www.fintech.finance/wp-content/uploads/2016/04/16-04-26-SPAContactless-Payment-Benefits-WP-Final.pdf

Taylor, S. and Todd, P.A. (1995) 'Understanding information technology usage: a test of competing models', Information Systems Research, Vol. 6, No. 2, pp.144-176.

Tompkins, M. (2015) Canadian Payment Methods and Trends: 2015, Canadian Payments Association, Ottawa, Canada.

Tornatzky, L.G. and Klein, K.J. (1982) 'Innovation characteristics and innovation adoptionimplementation: a meta-analysis of findings', IEEE Transactions on Engineering Management, Vol. 29, No. 1, pp.28-45.

Tsai, C.H., Zhu, D.S., Ho. B.C. T. and Wu, D.D. (2010) 'The effect of reducing risk and improving personal motivation on the adoption of knowledge repository system', Technological Forecasting and Social Change, Vol. 77, No. 6, pp.840-856.

Van der Heijden, H., Verhagen, T. and Creemers, M. (2003) 'Understanding online purchase intentions: contributions from technology and trust perspectives', European Journal of Information Systems, Vol. 12, No. 1, pp.41-48.

Venkatesh, V. and Davis, F.D. (2000) 'A theoretical extension of the technology acceptance model: four longitudinal field studies', Management Science, Vol. 46, No. 2, pp.186-204.

Venkatesh, V., Morris, M.G., Davis, G.B. and Davis, F.D. (2003) 'User acceptance of information technology: toward a unified view', MIS Quarterly, Vol. 27, No. 3, pp.425-478.

Wang, H. and Wu, S. (2014) 'Factors influencing behavioral intention to patronize restaurants using iPad as a menu card', Behaviour and Information Technology, Vol. 33, No. 4, pp.395-409.

Wang, Y.M. (2008) 'Determinants affecting consumer adoption of contactless credit card: an empirical study', CyberPsychology and Behavior, Vol. 11, No. 6, pp.687-689.

Wang, Y.S., Lin, H. and Luarn, P. (2006) 'Predicting consumer intention to use mobile service', Information Systems Journal, Vol. 16, No. 2, pp.157-179.

Wang, Y.S., Wang, Y.M., Lin, H. and Tang, T. (2003) 'Determinants of user acceptance of internet banking: an empirical study', International Journal of Service Industry Management, Vol. 14, No. 5, pp.501-519.

Wikipedia (2016) Contactless Payment, https://en.wikipedia.org/wiki/Contactless_payment

Wu, J.H. and Wang, S.C. (2005) 'What drives mobile commerce? an empirical evaluation of the revised technology acceptance model', Information and Management, Vol. 42, No. 5, pp.719-729.

Yang, S., Lu, Y., Gupta, S., Cao, Y. and Zhang, R. (2012) 'Mobile payment services adoption across time: an empirical study of the effects of behavioral beliefs, social influences and personal traits', Computers in Human Behavior, Vol. 28, No. 1, pp.129-142. 
Yi, M.Y., Jackson, J.D., Park, J.S. and Probst, J.C. (2006) 'Understanding information technology acceptance by individual professionals: toward an integrative view', Information and Management, Vol. 43, No. 3, pp.350-363.

YouGov (2012) Appetite for Contactless Card Technology but Banks and Retailers Need to do More, Research Finds, http://cdn.yougov.com/cumulus_uploads/document/mejjkkh38c/ Contactlesscards_pdf.pdf

Zaichkowsky, J.L. (1985) 'Measuring the involvement construct', Journal of Consumer Research, Vol. 12, No. 3, pp.341-352.

Zhang, L., Zhu, J. and Liu, Q. (2012) 'A meta-analysis of mobile commerce adoption and the moderating effect of culture', Computers in Human Behavior, Vol. 28, No. 5, pp.1902-1911.

Zhou, T. (2013) 'An empirical examination of continuance intention of mobile payment services', Decision Support Systems, Vol. 54, No. 2, pp.1085-1091. 